\title{
A photonumeric scale for the assessment of atrophic facial photodamage
}

DOI:

10.1111/bjd.16331

\section{Document Version}

Accepted author manuscript

Link to publication record in Manchester Research Explorer

\section{Citation for published version (APA):}

Ayer, J., Ahmed, A., Duncan-Parry, E., Beck, P., Griffiths, T. W., Watson, R. E. B., \& Griffiths, C. E. M. (2018). A photonumeric scale for the assessment of atrophic facial photodamage. The British journal of dermatology. https://doi.org/10.1111/bjd.16331

\section{Published in:}

The British journal of dermatology

\section{Citing this paper}

Please note that where the full-text provided on Manchester Research Explorer is the Author Accepted Manuscript or Proof version this may differ from the final Published version. If citing, it is advised that you check and use the publisher's definitive version.

\section{General rights}

Copyright and moral rights for the publications made accessible in the Research Explorer are retained by the authors and/or other copyright owners and it is a condition of accessing publications that users recognise and abide by the legal requirements associated with these rights.

\section{Takedown policy}

If you believe that this document breaches copyright please refer to the University of Manchester's Takedown Procedures [http://man.ac.uk/04Y6Bo] or contact uml.scholarlycommunications@manchester.ac.uk providing relevant details, so we can investigate your claim.

\section{OPEN ACCESS}


DR JEAN AYER (Orcid ID : 0000-0002-8574-090X)

DR RACHEL WATSON (Orcid ID : 0000-0002-5162-7503)

Article type : Original Article

\section{A photonumeric scale for the assessment of atrophic facial photodamage}

J. Ayer ${ }^{1,2^{\star}}$, A. Ahmed ${ }^{1}$, E. Duncan-Parry ${ }^{1}$, P. Beck ${ }^{1}$, T.W. Griffiths ${ }^{1,2}$, R.E.B. Watson ${ }^{1,2}$ and C.E.M. Griffiths $^{1,2}$

${ }^{1}$ Centre for Dermatology Research, Faculty of Biology, Medicine and Health, The University of Manchester, \& Salford Royal NHS Foundation Trust, Manchester Academic Health Science Centre, Manchester, UK.

${ }^{2}$ NIHR Manchester Biomedical Research Centre, Central Manchester University Hospitals NHS Foundation Trust, Manchester Academic Health Science Centre, UK

Corresponding author: Dr J Ayer, The Dermatology Centre, Salford Royal NHS Foundation Trust, Salford, UK. Tel: 44 (0) 161206 4081, Fax: 44 (0) 161206 0139, e-mail: jean.ayer@manchester.ac.uk

Funding sources: This work was supported by a programme grant from Walgreens Boots Alliance, Nottingham, UK.

This article has been accepted for publication and undergone full peer review but has not been through the copyediting, typesetting, pagination and proofreading process, which may lead to differences between this version and the Version of Record. Please cite this article as doi: $10.1111 /$ bjd.16331

This article is protected by copyright. All rights reserved. 
Conflict of interest: The authors state no relevant conflicts of interest. Walgreens Boots Alliance has approved submission of the manuscript but has exerted no editorial control of the content.

\section{Summary}

Background: Photonumeric scales have consistently shown superiority over descriptive equivalents. They have the advantage of providing a consistent visual frame of reference by minimising variability in perception and subjectivity. A photonumeric scale to assess hypertrophic facial photodamage already exists. However, there is currently no objective measure for atrophic facial photodamage. To address this, we have devised a nine-point photonumeric standardised scale.

Objectives: To design, test and validate a photonumeric scale for the assessment of atrophic facial photodamage against a descriptive scale for the same indication.

Methods: A pool of 393 facial photographs (en face and 45ำ oblique) from 131 individuals with atrophic facial photodamage was created. Five photographic standards were selected and assigned grades 0 through 8 , where 0 is no photodamage and 8 is severe atrophic photodamage, thus making a nine-point scale. Twenty photographs spanning the entire range of values were selected to test the scale. Testing was performed alongside a descriptive equivalent. A panel of 10 dermatologists, 10 non-dermatology clinicians and 14 dermatology scientists marked the two scales; marking was repeated one week later.

Results: There was a significantly greater agreement between the graders using the photonumeric scale than the descriptive scale (kappa values 0.71 and 0.37 with standardised errors of 0.57 and 0.17 respectively) with no significant difference in repeatability between the two methods $(p<0.05)$.

Conclusions: The study describes a new photonumeric scale for atrophic photodamage. This would be a useful adjunct in both the clinical and research settings.

This article is protected by copyright. All rights reserved. 


\section{What's already known about this topic?}

- Photonumeric scales demonstrate consistent superiority when compared to descriptive equivalents.

- Hypertrophic facial photodamage has been assessed successfully in terms of both severity and treatment response using a well-established photonumeric scale.

\section{What does this study add?}

- A new photonumeric scale created and validated for the assessment for a newly recognised clinical phenotype of facial photodamage - atrophic photodamage.

\section{What is the translational message?}

- Atrophic facial photodamage is known to be permissive for the development of keratinocyte carcinoma. Thus, any technology that allows clinicians to easily recognise and measure this form of photodamage will be a welcome addition to dermatological practice.

\section{Introduction}

It has been long established that photodamage or extrinsic ageing is a largely preventable and treatable entity which is readily distinguishable from chronological or intrinsic ageing ${ }^{1,2}$. What is less well-established is the diagnosis and evaluation of extrinsic ageing, a skill not traditionally taught amongst dermatologists. In fact, photodamage often goes unrecognised clinically, and thus is misdiagnosed as accelerated or severe intrinsic ageing. Furthermore, it is only recently that more than one form of facial photodamage exists amongst individuals with lightly pigmented skin (Fitzpatrick phototypes I-III; previously termed Caucasian) ${ }^{3,4}$.

The clinical assessment of photodamage requires a subjective evaluation of characteristic features, and has been influenced by inter-observer differences in grading criteria ${ }^{5}$. The assessment is often based upon a visual and tactile inspection of the skin, and an evaluation of generalised characteristic features such as fine and coarse wrinkling, pigmented lesions, colour, roughness, and telangiectasia ${ }^{6,7}$. In 1992, a photonumeric tool was developed for the assessment of a specific subgroup of photodamage termed hypertrophic photodamage ${ }^{8}$. Hypertrophic facial photodamage encompasses thick coarse wrinkling and skin laxity, a leathered and rough skin texture with elastoidosis, dyspigmentation, and often solar comedones as seen in Favre Racouchet syndrome ${ }^{9}$. However, a second subgroup of facial photodamage has now been described in which individuals 
have thin, shiny, glossy, atrophic skin with telangiectasia, minimal wrinkling and an increased frequency of actinic keratoses and keratinocyte cancers ${ }^{10,11}$. This is termed atrophic photodamage.

A photonumeric scale developed for the assessment of increasing severity of atrophic facial photodamage has not thus far been published in the literature. This is primarily because atrophic facial photodamage has only very recently been characterised in the literature. The purpose of developing such a scale for this indication is two-fold: (i) this phenotype denotes an increased susceptibility to the development of keratinocyte carcinoma ${ }^{11}$, thus it is important for clinicians to be able to recognise it clinically and; (ii) as with all forms of photodamage, it is readily preventable.

Descriptive scales have historically proven to be less user-friendly and a poorer assessment tool for photodamage. Numerous photonumeric scales are published in the literature, each with a specific focus on different aspects of skin disease; photodamage and its constituents is no exception ${ }^{12-14}$. The photonumeric scale for hypertrophic cutaneous facial photodamage ${ }^{8}$ is perhaps the best example. We have produced a similar photonumeric grading system to assess atrophic cutaneous facial photodamage. The resulting scale is based on high-quality photographic standards and was tested for both inter-grader and intra-grader agreement.

\section{Patients, Materials and Methods}

Local ethical approval was obtained from the Greater Manchester Central NHS Research Committee (research ethics committee reference 13/NW/0723). Written informed consent was obtained from the volunteers and the study adhered to Declaration of Helsinki principles. In total, 131 volunteers took part in the study, (71 males; 60 females; age range 54-98 years). All volunteers selected for the study were classified as Fitzpatrick sun reactive skin types I-III.

Three hundred and ninety-three facial photographs were taken with Cannon EOS D30 camera (en face and $45^{\circ}$ oblique), of 131 atrophic photodamaged individuals presenting to outpatient Dermatology departments in Salford Royal NHS Foundation Trust and East Cheshire Trust, UK. Each subject was photographed against a black backdrop and wore a dark drape with their hair removed from sight where appropriate by use of a headband to avoid obscuring the face. From this pool, 9

This article is protected by copyright. All rights reserved. 
photographic standards were selected as representative examples of atrophic photodamage and assigned grades 0 through 8 , thus making a nine-point scale where 0 is no photodamage and 8 is severe atrophic photodamage (figure 1). A further 20 photographs were selected which were thought to best represent and span the entire range of values.

The standards were selected on their ability to adequately portray the non-tactile and easily photographable factors of atrophic photodamage, i.e., thin, shiny, telangiectatic skin. A pilot study was performed by PB and ED using selected photographic anchors. The results of the pilot study were used to determine which photographic standards were selected for the photonumeric scale.

To test the agreement and repeatability of the photonumeric scale, it was compared against a descriptive scale developed for this study, as there was no conventional descriptive written scale in existence for the grading of atrophic skin. The descriptive scale used the following parameters: telangiectasia, skin thinning and fragility, glossy skin texture and skin smoothness. Each of these parameters could have a score assigned between 0 and 2, 0 being absent, 1 being mild, and 2 being severe. This allowed a rater to assign a minimum score of 0 and a maximum score of 8 .

Agreement, in this context, is the degree to which the grader gave the test photographs a score identical to that which has already been assigned to the image. Repeatability, however, refers to the ability of each grader to exactly reproduce that original score at a subsequent time, having allowed enough time to elapse so that memory is not a likely factor. The time between each grading session was one week.

The grading panel was split into three groups: 10 dermatologists (senior registrars and consultants), 10 clinicians trained in specialties other than dermatology and 14 dermatology scientists (expert in skin biology but not formally clinically trained). The panel graded the 20 photographs using the photonumeric scale and the descriptive scale alongside one another. Upon grading the same images a week later, the order of the photographs was randomised to further reduce the chances of the respondents' memories affecting the results. An exemplar photograph is included with the graders' responses (Figure 2).

This article is protected by copyright. All rights reserved. 


\section{Results:}

When analysing the raw data, there was more agreement between graders' scores when the photonumeric scale (65.5\%) was used as compared to the descriptive scale (47.5\%) (table 1). Kappa Cohen scores for the photonumeric and descriptive scale were calculated and demonstrated the reliability of the photonumeric scale over the descriptive scale; the kappa values were 0.71 and 0.37 with a standardised error of 0.57 and 0.17 respectively $(p<0.05$; table 2$)$. These results indicate substantial inter-observer agreement amongst graders using the photonumeric scale as compared to only fair agreement amongst graders using the descriptive scale.

Repeatability of the photonumeric scale was demonstrated by a paired Students t-test, with no significant difference between the graders taken at the two-time points (coefficient of variance of $9.02 \%)$.

\section{Discussion}

Results of this study indicate that application of a newly devised, nine-point photographic scale results in consistent and reproducible clinical evaluations of overall photodamage severity. We have developed a new photonumeric scale for the assessment of atrophic facial photodamage. Comparing the descriptive and photonumeric scales, it became apparent that specialist dermatology training increases the inter-observer agreement of both the photonumeric and descriptive scales. This could explain why the dermatology scientists overall performed better and more consistently with their rating and use of the scales compared to non-dermatology doctors. Although dermatology scientists are not explicitly taught dermatology clinical skills, they work closely with dermatologists and thus will have more exposure in this field. The non-dermatology clinicians had the poorest repeatability of any group, which may be explained by their reduced experience managing photodamage.

The inter-observer agreement was greater with the photonumeric scale across all groups. The percentage of images with more than half of graders in agreement with the score was higher when the photonumeric scale was used. This was greatest with dermatologists, where $70 \%$ of photographs had at least half of the graders in agreement using the photonumeric scale, compared to $40 \%$ with the

This article is protected by copyright. All rights reserved. 
descriptive scale. Non-dermatology clinicians ( $25 \%$ vs $15 \%)$ and dermatology scientists ( $50 \%$ vs $35 \%)$ consistently demonstrated the superiority of the photonumeric scale over the descriptive equivalent.

This study set demonstrates the superior inter-observer agreement of a photonumeric atrophic scale (Kappa Cohen 0.71) when compared with the written descriptive scale (Kappa Cohen 0.37) for the assessment of photodamaged facial skin. The 9 photographic standards of en face and $45^{\circ}$ facial views provide an easy-to-use evaluation system for the clinician involved in the assessment and treatment of photodamaged skin.

The demonstration that this photonumeric scale is a reliable tool in the assessment of photodamage allows its use for a variety of indications. Atrophic photodamage is more prone to developing keratinocyte cancers. Identification and classification of atrophic photodamage could be important for monitoring at risk patients and could prevent the increasing number of cases of keratinocyte carcinoma ${ }^{2}$. The photonumeric scale has the potential to aid with epidemiological studies of skin ageing in different countries and climates as the results have greater inter and intra-observer repeatability across different graders.

The photonumeric scale demonstrates superiority and can be used outside clinical settings. It has a role in categorising groups of photodamaged subjects prior to treatment with skin repair agents, thereby obtaining consistent and uniform groupings of subjects, e.g., those with mild to severe photodamage. This would allow greater reliability among centres involved in photodamage studies and enable independent regrading of good quality study photographs.

In conclusion, this new nine-point photographic scale, which shows strong repeatability and reproducibility, should be useful in categorising atrophic subjects in epidemiological studies where photodamage severity is either studied, or thought to be a factor in the relevant endpoint. The scale will also be useful in characterising atrophic individuals entering clinical trials for treatment of photodamage or for conditions where atrophic photodamage severity is a relevant cofactor.

This article is protected by copyright. All rights reserved. 
Figure 1: Photonumeric scale used for the assessment of atrophic cutaneous photodamage.

Five photographic standards (en face and 45 degree oblique) illustrating increasing severity of atrophic photodamage, where grade 0 represents no damage; grade 2, mild photodamage; grade 4, moderate photodamage; grade 6 , moderate/severe photodamage; and grade 8 , severe photodamage

This article is protected by copyright. All rights reserved. 

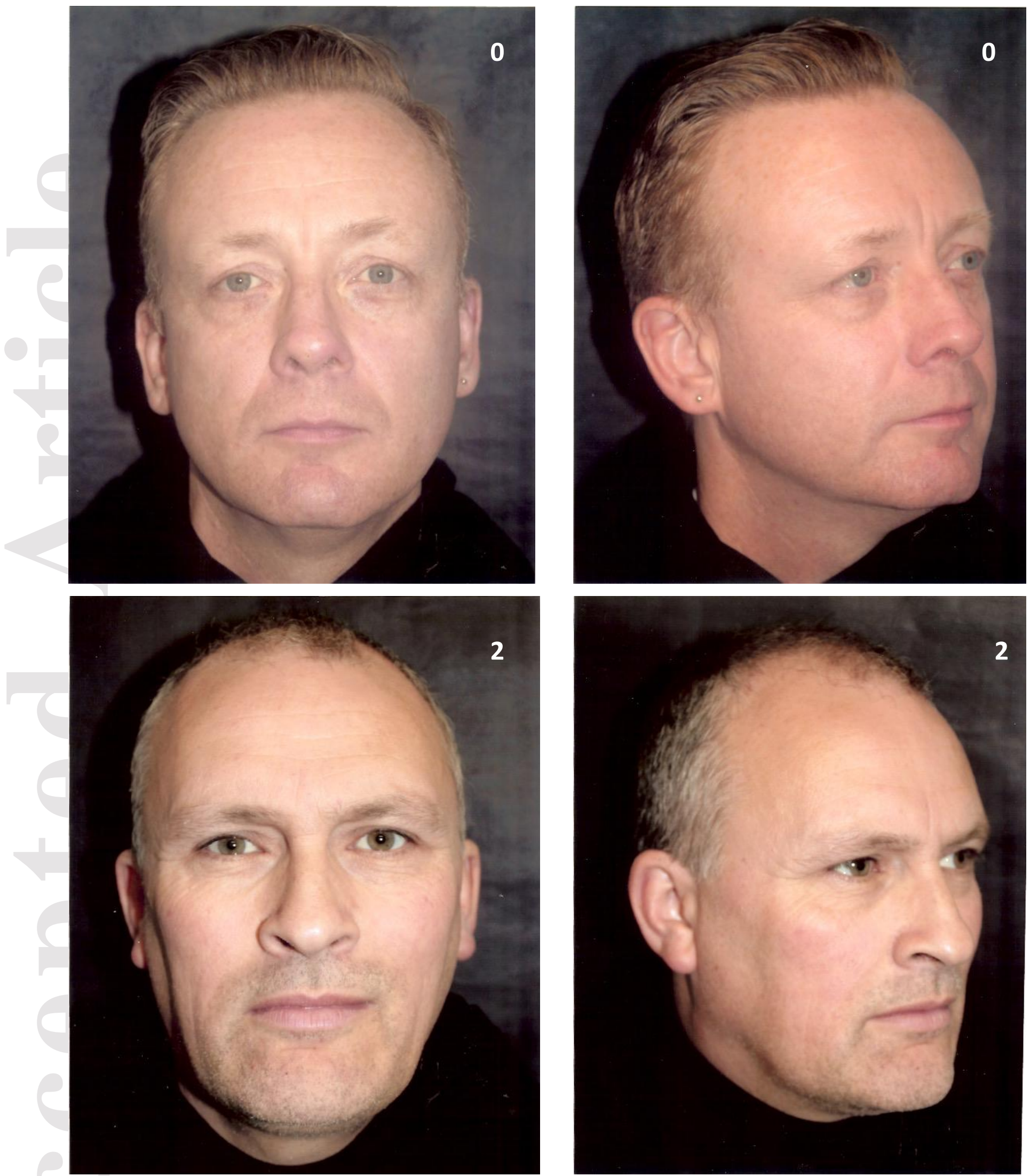

This article is protected by copyright. All rights reserved. 

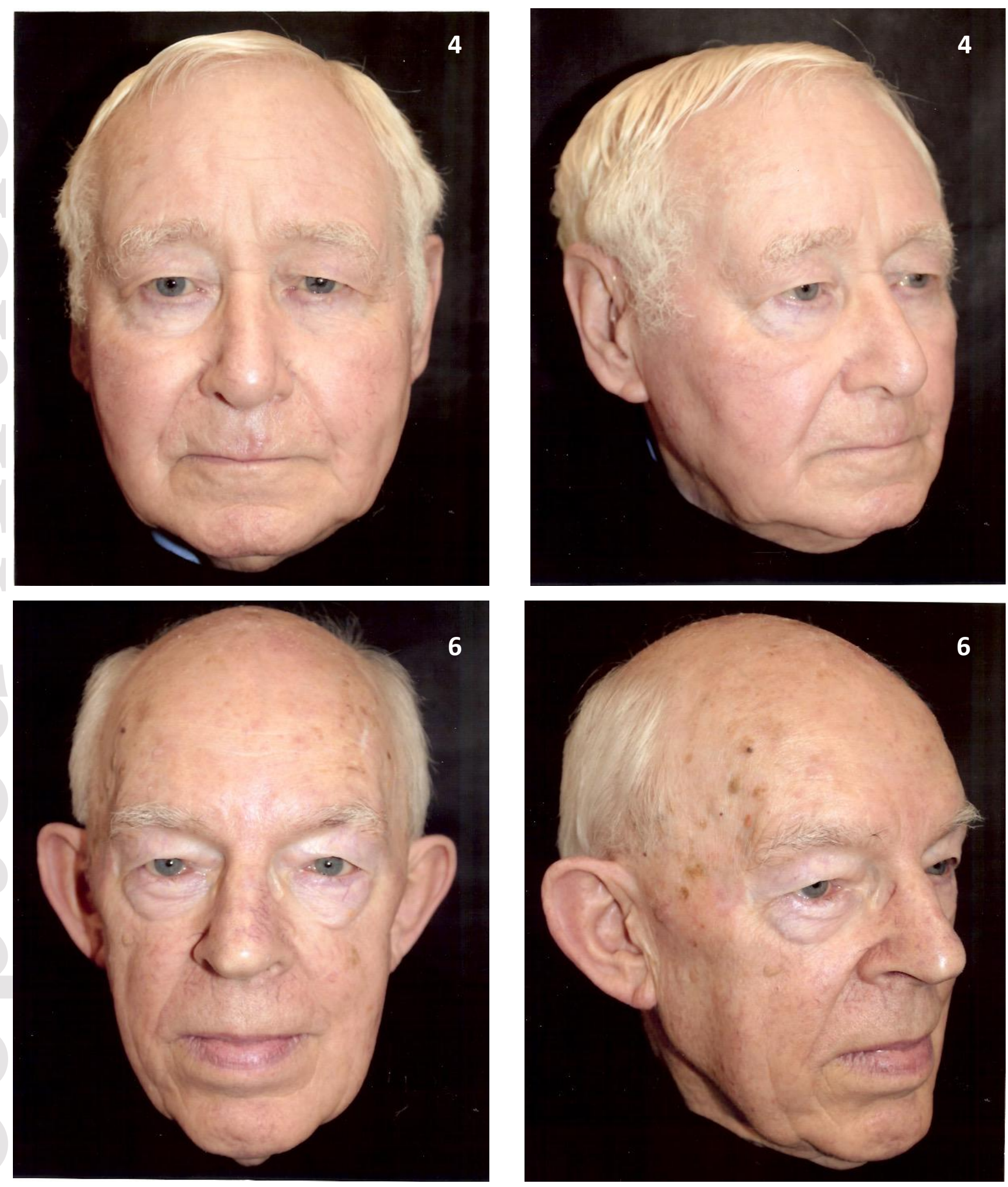

This article is protected by copyright. All rights reserved. 

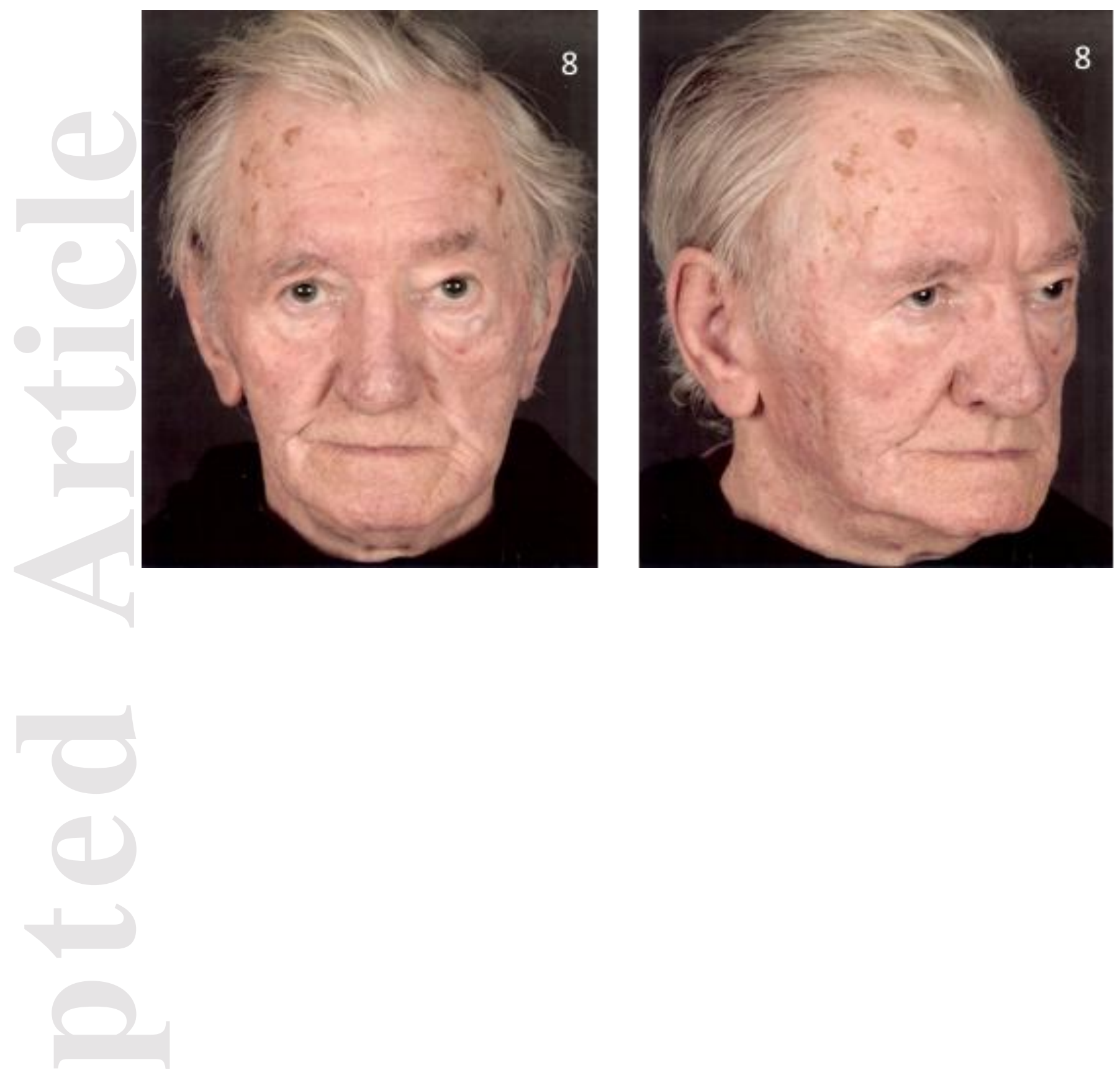

This article is protected by copyright. All rights reserved. 
Figure 2: Example of subject photograph and average grading scores

Example subject photograph (en face and 45 degree oblique) with average scores from photonumeric and descriptive scales of the Dermatologists, Dermatology Scientists and Non-Dermatology Clinicians as compared to Principal Investigator.

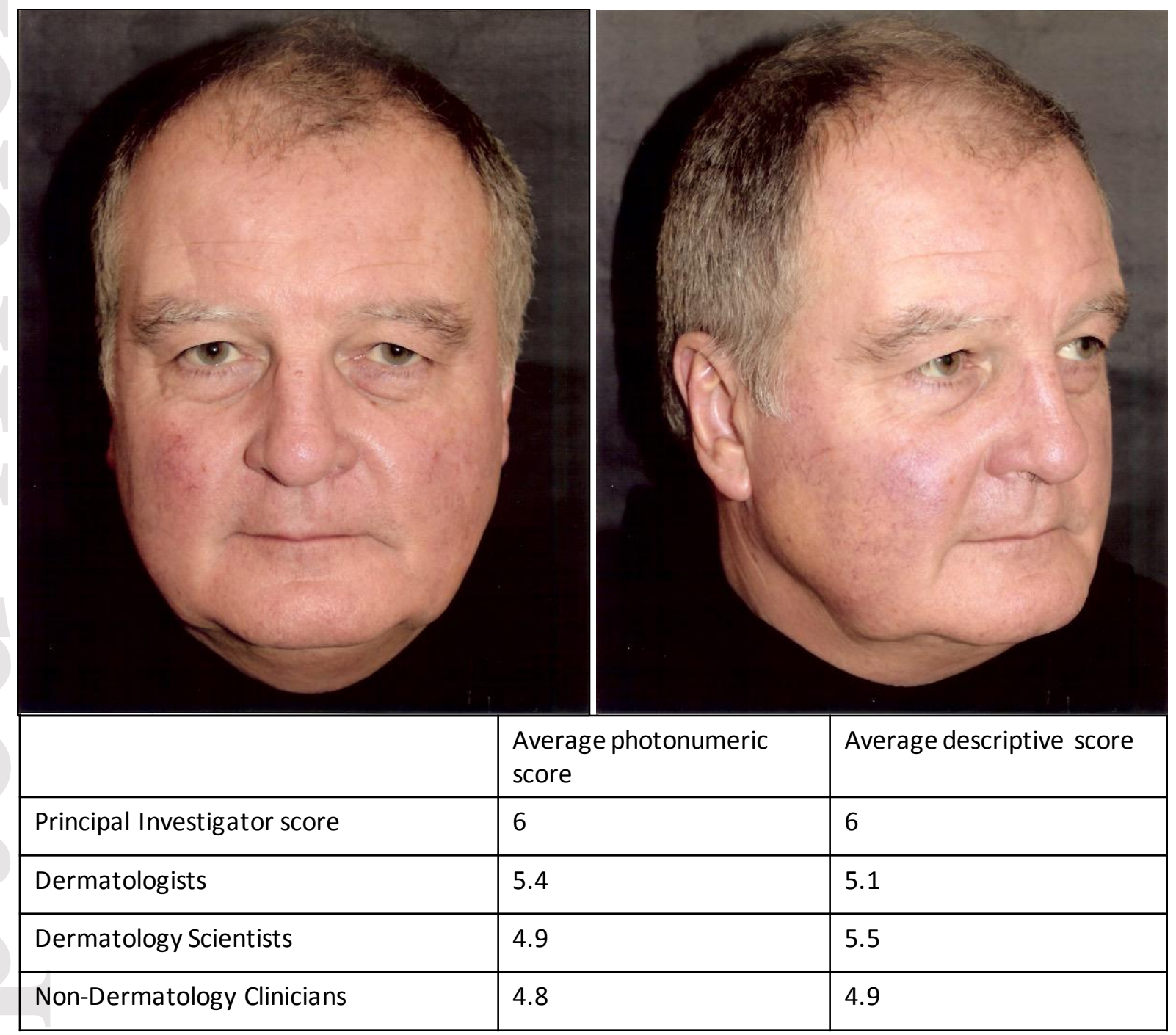

This article is protected by copyright. All rights reserved. 
Table 1: Comparison of inter-grader agreement in the evaluation of 20 atrophic photodamaged subjects using a photonumeric vs a descriptive grading scale by dermatologists, non-dermatology clinicians and dermatology scientists.

\begin{tabular}{|c|c|c|}
\hline Groups & $\begin{array}{c}\text { Number of images for which } \\
>50 \% \text { of graders were in } \\
\text { agreement using the } \\
\text { Photonumeric Scale }\end{array}$ & $\begin{array}{c}\text { Number of images for which }>50 \% \text { of } \\
\text { graders were in agreement using the } \\
\text { Descriptive Scale }\end{array}$ \\
\hline Dermatologists & 14 & 8 \\
\hline $\begin{array}{c}\text { Non-Dermatology } \\
\text { Clinicians }\end{array}$ & 6 & 3 \\
\hline Dermatology scientists & 13 & 7 \\
\hline
\end{tabular}

Table 2: Inter-rater reliability. The agreement between different assessors, as measured by the Cohen's Kappa Co-efficient identifies the superiority of the photonumeric over the descriptive scale.

\begin{tabular}{|l|l|l|}
\hline & Photonumeric & Descriptive \\
\hline Kappa Cohen Score & 0.709 & 0.373 \\
\hline Asymptotic Standardised Error & 0.568 & 0.166 \\
\hline Significance (p-value) & 0.003 & 0.269 \\
\hline
\end{tabular}

This article is protected by copyright. All rights reserved. 


\section{References}

(1) Taylor, C. R.; Stern, R. S.; Leyden, J. J.; Gilchrest, B. A. Photoaging/photodamage and photoprotection. Journal of the American Academy of Dermatology 1990, 22, 1-15.

(2) Stanulis-Praeger, B. M.; Gilchrest, B. A. Effect of donor age and prior sun exposure on growth inhibition of cultured human dermal fibroblasts by all trans-retinoic acid. Journal of cellular physiology 1989, 139, 116-124.

(3) Lober, C. W.; Fenske, N. A. Photoaging and the skin: differentiation and clinical response. Geriatrics 1990, 45, 36-40, 42.

(4) Wlaschek, M.; Tantcheva-Poor, I.; Naderi, L.; Ma, W.; Schneider, L. A.; Razi-Wolf, Z.; Schuller, J.; Scharffetter-Kochanek, K. Solar UV irradiation and dermal photoaging. Journal of photochemistry and photobiology. B, Biology 2001, 63, 41-51.

(5) Larnier, C.; Ortonne, J. P.; Venot, A.; Faivre, B.; Beani, J. C.; Thomas, P.; Brown, T. C.; Sendagorta, E. Evaluation of cutaneous photodamage using a photographic scale. Br. J. Dermatol. 1994, 130, 167-173.

(6) Gilchrest, B. A. Skin aging and photoaging: an overview. J. Am. Acad. Dermatol. 1989, 21, 610-613.

(7) Leyden, J. J. Clinical features of ageing skin. Br. J. Dermatol. 1990, 122 Suppl 35, 1-3.

(8) Griffiths, C. E.; Wang, T. S.; Hamilton, T. A.; Voorhees, J. J.; Ellis, C. N. A photonumeric scale for the assessment of cutaneous photodamage. Arch. Dermatol. 1992, 128, 347-351.

(9) Favre, M.; Racouchot, J. [Nodular cutaneous elasteidosis with cysts and comedones]. Ann. Dermatol. Syphiligr. (Paris). 1951, 78, 681-702.

(10) Ayer J; Watson, R. G., TW; Griffiths, CEM: A comparison of atrophic and hypertrophic facial photoageing. In European Society of Dermatology Research; Journal Investigative Dermatology: Rotterdam, 2015; Vol. 135; pp S32-34.

(11) Brooke, R. C.; Newbold, S. A.; Telfer, N. R.; Griffiths, C. E. Discordance between facial wrinkling and the presence of basal cell carcinoma. Arch. Dermatol. 2001, 137, 751-754.

(12) Carruthers, J.; Jones, D.; Hardas, B.; Murphy, D. K.; Donofrio, L.; Sykes, J. M.; Carruthers, A.; Creutz, L.; Marx, A.; Dill, S. Development and Validation of a Photonumeric Scale for Evaluation of Volume Deficit of the Temple. Dermatologic surgery : official publication for American Society for Dermatologic Surgery [et al.] 2016, 42 Suppl 1, S203-s210.

(13) Niforos, F.; Liew, S.; Acquilla, R.; Ogilvie, P.; Safa, M.; Signorini, M.; Jones, D.; Hawthorn, J.; Collins, C.; Kerson, G.; Sithamparanathan, M. Creation and Validation of a Photonumeric Scale to Assess Volume Deficiency in the Infraorbital Region. Dermatologic surgery : official publication for American Society for Dermatologic Surgery [et al.] 2017, 43, 684-691.

(14) Buchner, L.; Vamvakias, G.; Rom, D. Validation of a photonumeric wrinkle assessment scale for assessing nasolabial fold wrinkles. Plastic and reconstructive surgery 2010, 126, 596-601.

This article is protected by copyright. All rights reserved. 